\title{
ZOOPLANKTON OF THE SUAPE AREA (PERNAMMBUCO-BRAZIL)2
}

\author{
MARYSE NOGUEIRA PARANAGUĀ ${ }^{2}$ \\ Departamento de Oceanografia da \\ Universidade Federal de Pernambuco
}

\section{RESUMO}

Neste trabalho sầ apresentados os resultados relativos a anālise de 120 amostras de plāncton coletadas no perĩodo de um ano em 11 (onze) estações fixas localizadas na bała de suape, estuārios dos rios Massangana, Tatuoca e Ipojuca. São discutidos aspectos relativos à distribuição qualitativa e quantitativa da população zooplanctōnica. Dentre os organismos representados na ārea podemser citados os Copepoda Paracalanus crassirostris, Euterpina acutifrons, Centropages velificatus, Macrosetella gracilis, Coricaeus giesbrechti, Acartia lilljeborghi, Temora stylifera, oithona hebes, 0. oswaldocruzi, Notodiaptomus; os Cladocera Bosmina spp., Daphnia spp., os Rotifera Brachyonus plicatilis, B. falcatus, Mytilina ventralis, Rotaria rota toria; Hydromedusae; Siphonophora e Dolium sp., Lucifer faxoni e lar vas de Copepoda, Polychaeta, Bivalvia (Mytelza charruana, M. guyanen sis), Brachyura, Natantia, Echinodermata e Peixes.

\section{ABSTRACT}

One hundred and twenty samples of plankton were studied in 11 fixed stations, located in suape Bay and in the estuaries of Massangana, Tatuoca and Ipojuca Rivers. The quantitative and qualita tive distribution of the zooplanktonic population in discussed. The better represented organisms in the studied area were: the Copepoda Paracalanus crassirostris, Euterpina acutifrons, Centropages velificatus, Macrosetella gracilis, Corycaeus giesbrechti, Acartia lilljeborghi, Temora stylifera, Oithona hebes, 0. oswaldocruzi, Notodiaptomus; the Cladocera Bosmina spp. and Daphnia spp.; the Rotifera

1 This work supported by the CONDEPE.

2 Scholarship of the Conselho Nacional de Desenvolvimento Científico e Tecnológico $(\mathrm{CNPq})$.

Trab. Oceanogr. Univ. Fed. PE., 19: 113-124, 1985/86 
Brachionus plicatilis, B. falcatus, Mytilina ventralis, Rotaria rota toria; Hydromedusae; Siphonophora; Doliolum, Lucifer taxoni and Iar vae of Copepoda, Polychaeta, Bivalvia (Mytelza charruana, M. guyanen sis), Brachyura, Natantia, Echinodermata and Pisces.

\section{INTRODUCTION}

An industrial port complex is being built by the state Government in Suape Bay, situated between $08^{\circ} 14^{\prime}$ and $08^{\circ} 29^{\prime} S$ (Northe astern Coast of Brazil), whïch will inevitably cause environmental changes in the surrounding areas. For this reason, an ecological study was carried out so as to relate the present conditions with the possible future effects on the implementation of the project. The study puts forward proposals and suggestions in order to reduce the negative effects on the environment. Samples were collected for physico-chemical study of the water and for analys is of the plankton and benthos (CONDEPE, 1983).

The main object of this paper is to characterize the quan titative and qualitative distribution of the zooplanktonic poputation.

Among the published papers relative to estuarine zooplank ton on Pernambuco coast, the following merit attention PARANAGUA (1966), PARANAGUA (1985), PARANAGUĀ et ali i (1979), PARANAGUA andGUS MAOO (1980), PARANAGUA and NEUMANN-LEITÃO $(1980,1981)$ and NASCIMENTO (1981). PARANAGUA and NASCIMENTO-VIEIRA (1984) however, for the Suape area there are only few data published by CAVALCANTI et alii (1980), CONDEPE (1983) and NEUMANN-LEITAO (1986). The present work is a contribution to the knowledge of the zooplankton of the suape area.

\section{AKNOWLEDGMENT}

This research was supported by the State Government of Pernambuco through the Institute of Development of Pernambuco (CONDEPE).

I am very grateful to Dr. E. Eskinazi-Leça and Ms. A.L.T. Lyra for the critical comments and numerous suggestions on the original manuscript.

I would also like to thank Ms. D. A. Nascimento-Vieira and Ms. S. Neumann-Leitão for the copepods and rotifers species confirmation.
DESCRIPTION OF THE AREA

Localization: The studied area is located on the Pernambuco State coast (Northeastern Brazil) between $08^{\circ} 14^{\prime}$ and $08^{\circ} 29^{\prime} S$ (Fig. - 1)

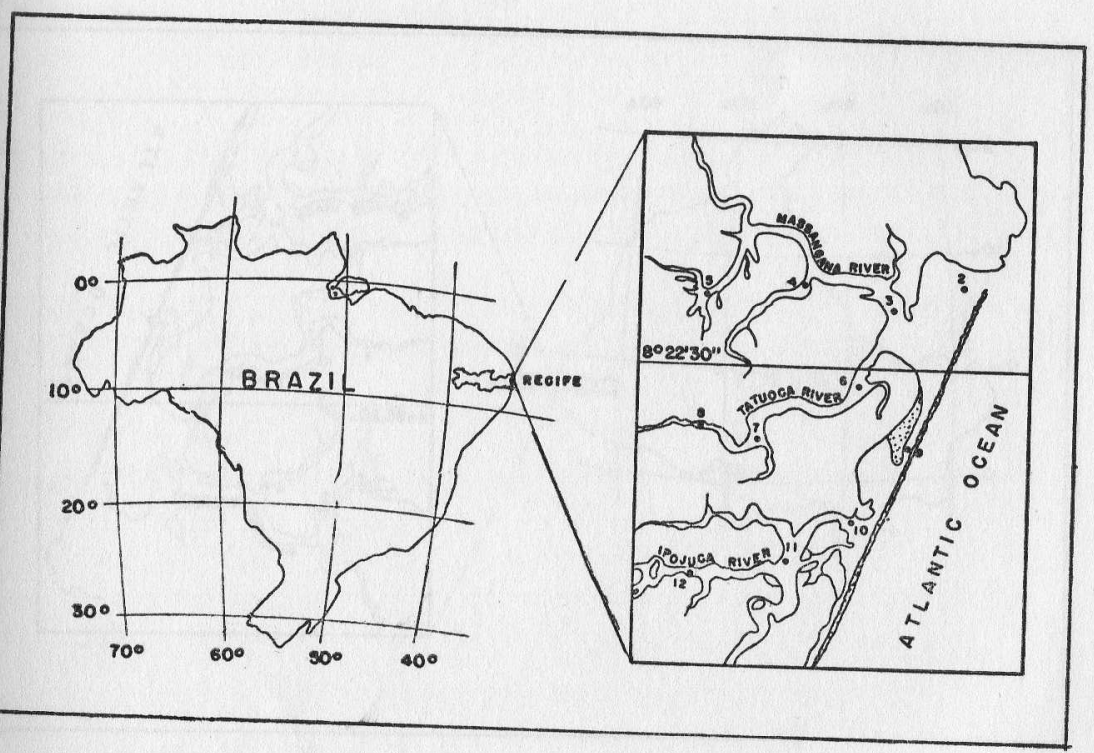

Fig. 1 - Studied ore and Station locotion. 
Climate and Rainfall: The area presents an As' type of climate, which is considered by ANDRADE and LINS (1971) as warm "pseudo-tropi cal" showing a dry season (rainfall less than $100 \mathrm{~mm} /$ year) between September and February and a rainy season from March to August with rainfall between $1850 \mathrm{~mm} /$ year and $2.364 \mathrm{~mm} /$ year (ANDRADE, 1978).

The maximum air temperature was $34^{\circ} \mathrm{C}$ the minimum $20^{\circ} \mathrm{C}$ and the average value corresponded to $27^{\circ} \mathrm{C}$ (ESKINAZI-LECA and KOENING, in press).

Hydrography: Many hydrographic basins are within the area with higher concentration at the south of Santo Agostinho Cape. The main rivers draining the region are Massangana, Tatuoca and Ipojuca, all of them converging to Suape's Bay. The Ipojuca River is considered perennial in all its course and it is the one that discharges the largest water volume having, therefore, a strong influence on all the Suape Bay.

Hydrology: Studies carried out by CAVALCANTI et alii(1980) and CONDE PE(1983) showed the following hydrological characteristics for the region: the temperature was stable both horizontally and vertically and varied from $26^{\circ} \mathrm{C}$ to $29^{\circ} \mathrm{C}$. The salinity showed the widest varia tion, ranging from that of a true marine environment (salinity $30 \%$ to a 1 imnetic one $(<0,5 \% / 00)$.

MACEDO and CAVALCANTI (1979) established for this region, three distinct salinity regimes which can be summarized as follows:

- euhaline-polyhaline regime (salinity between $35^{\circ} / 00$ and $18 \%$ ) at the Suape Bay and the proximity of the rivers' mouth (station 2,3 , $4,6,9$ and 10 ).

- mesohaline regime (salinity between $18^{\circ} / 00$ and $0,5 \%$ ) in the mid dle estuary of Massangana, Tatuoca and Ipojuca Rivers (stations 5 , 7,8 and 11 )

- oligohaline-limnetic regime (salinity $<0,5^{\circ} / 00$ ) found only in the upper estuary of the Ipojuca River (station 12) and eventually at the stations located upstream of Massangana and Tatuoca Rivers.

The 1 imits of these regimes can vary according to the season and the tide dynamics.

The dissolved oxygen level in the water varied from 2 to $5 \mathrm{~m} \ell / \ell$, the lowest value observed at the Massangana River estuary and mainly in the estuary of Ipojuca River when it reached om $\ell / \ell$ during some periods (CAVALCANTI et alii, 1980).
MATERIAL AND METHODS

One hundred and twenty samples of plankton were studied, collected according to the tide regime, every two months at 11 fixed stations. These samples were collected with a net $65 \mu \mathrm{m}$ mesh size, ho rizontaly hauled at the surface during 5 minutes. After the collection the samples were preserved in $4 \%$ Formalin buffered with sodium borate. The organisms were counted in subsamples of $2 \mathrm{~m} \ell$ removed with a stempe1-pipette. The frequency of occurrence was calculated from the percentage of samples in which each organisms occurred in relation to the total number of samples. The following nomenclature was used

$$
\begin{aligned}
&>80 \% \text { - very frequent } \\
& 80 \%-1-30 \% \text { - frequent } \\
& 30 \%-10 \% \text { - not frequent } \\
& \leqq 10 \% \text { - sporadic }
\end{aligned}
$$

RESULTS

The zooplanktonic population of the studied area is repre sented by several organisms indicated in the figure 2. A brief comment on some of these organisms follows.

Foraminifera: generally benthic. However there are some important species in the plankton. Although not abundant they presented a frequency superior to $50 \%$. Among the identified genera Gzobigerina, abundant in tropical seas, called attention.

Radiolaria: exclusively marine. They occured in the stations located at the bay and in the estuaries of Massangana and Tatuoca Rivers, and very seldom in the Ipojuca River, at high tide.

Tintinnida: very common in tropical seas, they were dominant during some periods of the year. Their frequency of occurrence was $28 \%$, in the bay stations and estuaries of Massangana and Tatuoca Rivers, but they were sporadic in the station at Ipojuca River.

Hydromedusae: they played an important role as biological indicators, and although not frequent, they were characteristic of the marinepolyhaline regime environment.

Rotifera: common organisms in freshwater environments, they were 
found in station 10,11 and 12 , being very abundant in Ipojuca River In December they reached more than 100.000 individuals in the total sample. When present in great quantity, they can quickly consume all the available food.

Gastropoda: with a frequency of more than $80 \%$ they were found in nearly all stations and during all tide.

Cladocera: exclusively planktonic, they inhabit the surface layer. The genus Penizia was frequent at the stations with euhaline-polyhaline regime. The genera Daphnia and Bosmina were frequent at the sta tions with a oligohaline-limnetic regime. Members of these genera are capable of living in a low dissolved oxygen concentration.

Copepoda: This was the most expressive group among the crustacearis, and numerically the most important of the zooplankton. Among the identified species the following were more important paracalanuscras sirostris, Calanopia americana, Euterpina acutifrons, Acartia lillje borghi, Oithona hebes, o. oswaldocruzi and Diaptomus spp.

Other groups: species of the genus Appendicularia(Chordata) and species of the genus sagitta (Chaetognatha) were frequent at the stations located in the bay and estuaries of Massangana and Tatuoca Rivers. Species of these genera are important as biological indicators.

The meroplanktonic larvae had an important role. At the Suape area, many organisms were found, especially those of economical importance such as fish, molluscs and Decapoda Crustaceans. Among the Decapoda larvae, shrimps and crabs were more abundant. The bival via larvae were represented by Crassostrea rhizophorae, Mytezla char rua and $M$. guyanensis. The frequency of $57 \%$ of these Bivalvia larvae occurred mainly during the high tide in all stations except in stations 11 and 12 of the Ipojuca River the other very frequent nisms (Fig. 2) were the Copepoda, the Polychaeta, and the Cirripedia larvae. The 01 igochaeta, fish larvae, 0stracoda, Insecta, Pteropoda, Bryozoa, Echinodermata larvae, Turbelaria, Siphonophora, Dolium and Lucifer were not frequent anit rare.
It is well known that estuarine regions are characterized by their unstable salinity because they are a dynamic system which receives a continuous discharge of freshwater, and where the denser water is pushed from the coastal to the inner parts of the stuary (CASPERS, 1967; JEFFRIES, 1967; TUNDISI, 1970).

The copepoda abundance is characterized by 4 or 5 dominant species a fact observed in different estuaries by such authors as RILEY (1967); TEIXEIRA et alii (1973); PERKINS (1974); RODRIGUEZ (1973), NASCIMENTO (1981) and ROCHA (1986).

In the studied area, the differences in the zooplankton abundance and composition were conditioned mostly, by the influence of the tide and of the freshwater brought in by the rivers.

The zooplankton of the stations located in the Suape Bay (Fig. 1) was qualitative and quantitatively more abundant; dominated the typical forms of -an environment with an euhaline-polyhaline regime. Among the Copepoda Paracalanus crassirostris, Euterpina acutifrons, Centropages velificatus, Acartia lilljeborghi, Macrosetella gracilis and Temora stilifera were frequent. According to BJÖRNBERG (1980) P. crassirostris is abundant and frequent in is land and coastal water, its abundance therefore to be expected in the area. species of Sagitta, Oikopleura and Rotifera with Brachionus plicatilis, besides Echinodermata larvae were frequent also.

In the stations of the middle estuary, especially, of the Massangana and Tatuoca Rivers organisms were dominant which characte rise environments with a polyhaline-mesohaline regime. Therefore those just mentioned were found in a smaller frequency. Among the copepo da, the most frequent were Oithona hebes and 0 . oswaldocrusi. FONSECA and BJÖRNBERG (1976) report that 0 . oswaldocruzi is more abundant in low salinity. MONTU and GOEDEN (1986) cited this species as eurihaline in the Patos Lagoon.

In the stations located at the Ipojuca River the association of organisms was quite distinct, characterized mostly by forms of an oligohaline-limnetic environment. The zooplankton was qualitatively poor. Among the Copepoda, species of Cyclops and Diaptomus were found the Cladocera were represented by Daphnia and Bosmina. Among the Rotifera $B$. plicatilis can be cited as more abundant in sa $l$ ine waters, $B$. falcatus and $B$. quadridentatus in limnetic environments and Mytilina ventralis and Rotaria rotatoria in more polluted areas. According to NEUMANN-LEITÃO (1986), these species in the Suape 
ments respectively, which the present results confirm.

According to MELO FILHO (1977), about six sugar cane plants and other kinds of industries are responsible for the pollution o this river, justifying the low level of dissolved oxygen observed in the area.

According to PENNAK (1953), species of Daphnia and Bosmina are capable of living very low concentrations of dissolved oxygen, thus explaining the occurrence of these organisms in this area.

PARANAGUA (1972) reports that Mytelza falcata larvae, al though euryhaline, are more frequent in polyhaline-mesohaline environments. In the suape region, these larvae were frequent in the estuary of Massangana and Tatuoca Rivers and almost absent in the Ipojuca River. This absence is associated to the low salinity and pollu tion.

In a general way, it can be concluded that the zooplankto nic association seems to characterize the suape as a very rich estua rine region.
ANDRADE LIMA, D. O Projeto Suape e a vegetação. Comunicação técni ca nọ 2. PECCIPS. Recife. 1978, 10 p.

ANDRADE, G. 0. and LINS, R. C. Os climas do Nordeste. In: VASCONCELOS SOBRINHO, J. ed. As regiões naturais do Nordeste, o meio e a civilização, CONDEPE, Recife, 1971. p. 95-138.

BJÖRNBERG, T.K. S. Revisão da distribuicão dos gêneros Paracazanus, Clausocalanus e Ctenocalanus(Copepoda, Crustacea) ao largo do Brasil. Boletim do Instituto Oceanográfico da Universidade de São Pau10, 29(2):65-8, 1980

CASPERS, H. Analysis of definitions and biological considerations. In: LAUFF, G. H. ed. Estuaries. Washington, American Association for the Advancement Science, Washington, 1967, p. 6-8. (Publication, 83).

CAVALCANTI, L. B.; COELHO, P. A.; ESKINAZI-LECA, E.; LUNA, J. A. C.; MACEDO, S. J. and PARANAGUA, M. N. Condiciones ecologicas de la area de Suape (Pernambuco-Brasil). In: Memorias del seminário sobre el Estudio Cientifico e Impacto Humano en el Ecosistema de Manglares, Montevideu, UNESCO, Oficina Regional de Ciência y Tec nologia para America Latina y el Caribe, 1980, p. 317-23.

CONDEPE. Sintese Ecológica. Caracterização do Complexo EstuarinoLagunar da ārea de Suape (Pernambuco-Brasil). Recife, 1983. v.1.

ESKINAZI-LECA, E. and KOENING, M. L. Distribuição das diatomáceas (Bacillariophyceae) na ārea de Suape (Pernambuco-Brasil). Ficol. Latinoamericana. (in press).

FONSECA, V. L. and BJÖRNBERG, T.K. S. Oithona oligohalina sp. n. de Cananéia (Estado de São Paulo) e considerações sobre Oithona ovaZis Herbst (Copepoda, Cylopoida). Anais da Academia Brasileira de Ciências, São Paulo, 47 (sup 1.):127-131, 1976.

JEFFRIES, H. P. Saturation of estuarine zooplankton by Congeneric Associates. In: LAUFF, G. H., ed. Estuaries. American Association for the Advancement of Science. Washington. 1967. p. 500508 (Publication, 83). 
MACEDO, S. J. and CAVALCANTI, L. B. Condições hidrolōgicas da ārea de Suape, Pernambuco-Brasil. Ciência e Cultura, São Paulo, 31 $(7): 426,1979$.

MELO FILHO, J.A.S. Caracterização da situação atual da ārea/proje to Suape sob o ponto de vista da poluicão ambiental. Comunica६ão Técnica 1. PECCIPS. Recife, 1970. 13 p.

MONTU, M. and GOEDEN, I. M. Atlas dos Cladocera e Copepoda (Crusta cea) do estuário da lagoa dos Patos (Rio Grande, Brasil). Neritica. Revista do Centro de Biologia Marinha da Universidade $\mathrm{Fe}$ deral do Paranā, Pontal do Sul, 1986. $134 \mathrm{p}$.

NASCIMENTO, D.A. Estudo Ecológico da Região de Itamaracā-Pernambuco, Brasil. XV. Copepoda do estuário do Rio Botafogo. Trabalho Oceanogräfico da Universidade Federal de Pernambuco, Recife, 16: $23-64,1981$.

NEUMANN-LEITAO, S. Sistemática e ecologia dos Rotỉferos (Rotatoria) planctônicos da ārea estuarina lagunar. de Suape. Pernambuco(Brasil) Recife, $1986,259 \mathrm{p}$. Tese de Mestrado. Universidade Federal de Pernambuco. Departamento de Oceanografia.

PARANAGUA, M. N. Sobre : p lâncton da região compreendida entre $3^{\circ}$ Lat. S e $13^{\circ}$ Lat.S ao largo do Brasil. Trabalhos do Instituto Oceanogräfico da Universidade Federal de Pernambuco, Recife, $\underline{5} / \underline{6}$ :125-39, 1966 .

- Distribuicão, ecologia e desenvolvimento de Mytelza fal cata (d'Orbigny, 1846) nos Estados do Rio de Janeiro e Guanabara. São Paulo, 1972. 65 p. Tese de Doutoramento. Universidade de São Paulo.

- Zooplankton of Suape area (Pernambuco-Brazi).

Bulletin of Marine Science, Miami, 37(2):773, 1985.

; NASCIMENTO, D. A. and MACEDO, S. J. Estudo ECológico da Região de Itamaracā, Pernambuco-Brasil, II. Distribuição do zooplâncton no estuārio do rio Igarassu. Trabalhos Oceanogrāficos da Universidade Federal de Pernambuco, Recife, 14:65-92, 1979.

and GUSMAO, L.M. O. A influência da metodologia na captação de larvas planctōnicas. In: Simpōsio Brasileiro de Aqüicultura, Academia Brasileira de Ciências, Rio de Janeiro, 1980:193204.
PARANAGUÃ, M. N. and NEUMANN-LEITAO, S. Estudo ecológico da região de I tamaracá, Pernambuco - zooplâncton dos viveiros decultivo de peixes de Itamaracá. PE. Revista Nordestina de Biologia, João Pes soa, $3: 187-206,1980$.

- and - Estudo ecológico da região de Itamaracā, Pernambuco-Brasil. XIII. Rotíferos planctōnicos dos viveiros de cultivo de peixes. In: IV Congresșo Brasileiro de Engenharia de Pesca, 2, Recife, 1981. 231-241.

- and NASCIMENTO-VIEIRA, D. A. Estudo ecológico da região de Itamaracá(Pernambuco-Brasil) XXV. Zooplâncton do rio Botafogo. Trabaihos Oceanogräficos da Universidade Federal de Pernambuco. Recife, 18:193-206, 1984 .

PENNAK, R. W. Fresh-water invertebrates of the United States, The Ronald Press Company, New York, 1953, 769 pp.

PERKINS, E. J. The biology of estuaries and Coastal Waters.Academic Press, London, 1974. 678 pp.

RILEY, G. A. The plankton of estuaries. In: LAUFF, G. H., ed. Estuaries, American Association for the Advancement of Science. Washington, 1967. p. 316-326 (Publication, 83).

ROCHA, C. E. F. Copepods of the Genus Oithona. Baird, 1843 from mangrove areas of Central and South America. Hydrobiologia, Nether 1 ands, 135:95-107, 1986.

RODRIGUEZ, G. El sistema de Maracaibo. Biology y Ambiente. Inst. Venezuelano Invest. Cient., Caracas, 1973, 395 pp.

TEIXEIRA, C.; TUNDISI, J. and KUTNER, M. B. Plankton studies in a mangrove environment. II - The standing stock and some ecological factors. Publicação Instituto Oceanogrāfico da Universidade de São Paulo, 208:13-41, 1973 .

TUNDISI, J. G. Plancton estuarino. Contribuicão do Instituto oceanográfico da Universidade de São Paulo, Servicos Oceanogrä́ficos, Biologia, 19:1-22, 1970 . 

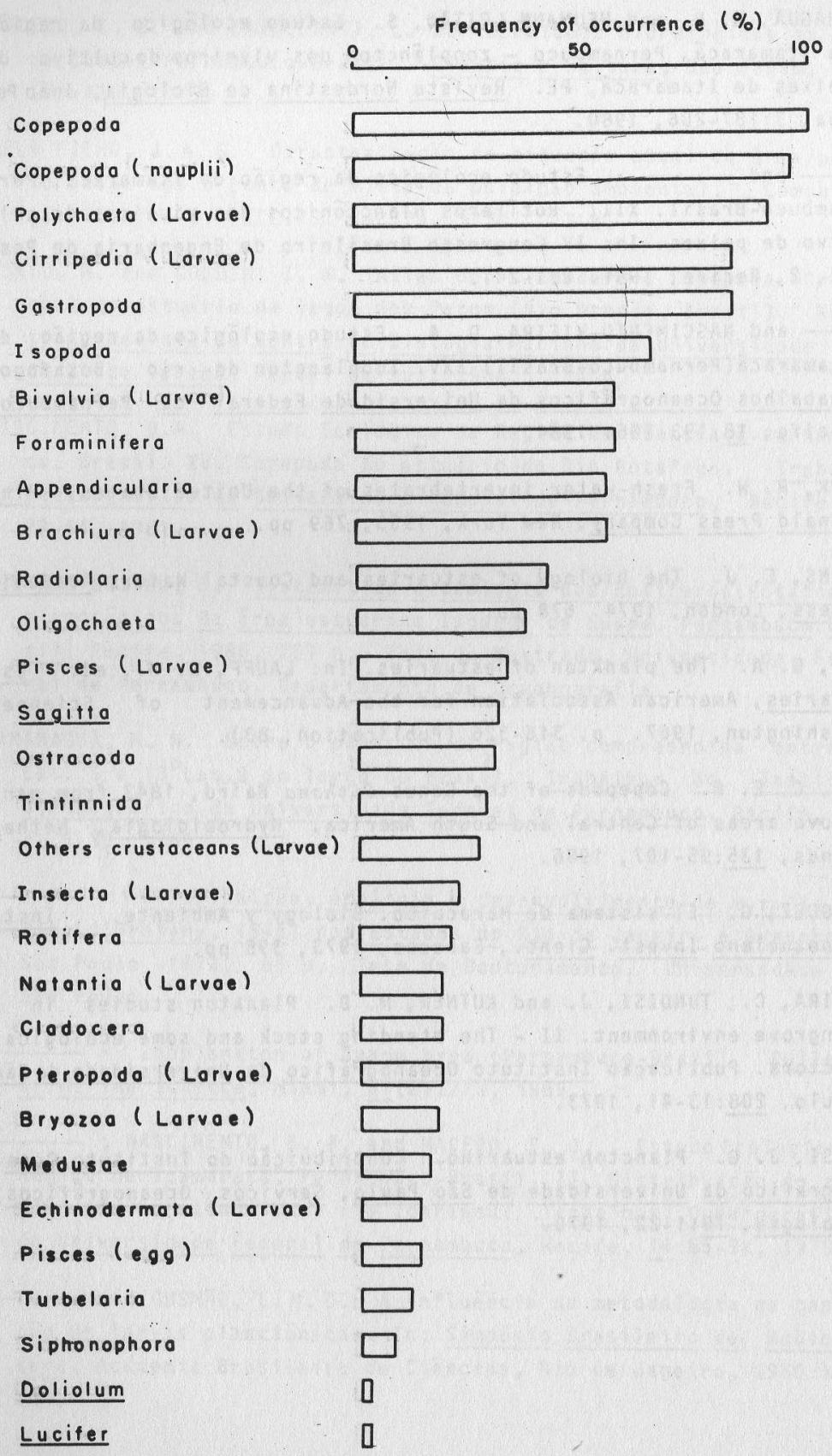

Fig. 2-Frequency of occurrence of the main zooplankton organisms in the Suape area PE.Brazt" 